ELORE (ISSN 1456-3010), vol. 17 - 1/2010.

Julkaisija: Suomen Kansantietouden Tutkijain Seura ry. [http://www.elore.fi/arkisto/1_10/ajankoht_stark_1_10.pdf]

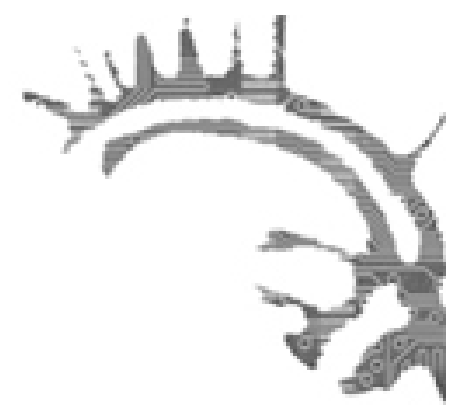

\title{
Presenting
}

\section{Mobile Technology, Gender and Development in Africa, India AND Bangladesh}

\section{$\underline{\text { Laura Stark }}$}

The anthropologically-oriented research project Mobile technology, gender and development in Africa, India and Bangladesh is based at the Department of History and Ethnology, University of Jyväskylä. Project members include Sirpa Tenhunen (Anthropology, University of Helsinki), Jukka Jouhki (Ethnology, University of Jyväskylä), Perpetual Crentsil (Anthropology University of Helsinki), and Sanna Tawah (Ethnology, University of Jyväskylä). The project is funded by the Academy of Finland (2010-2013) and led by Professor Laura Stark (University of Jyväskylä). Project members will conduct empirical, interview-based field research in Africa and South Asia on the new opportunities and challenges offered by mobile technologies for women and girls, and how mobile technologies are already impacting gender relations in these areas. Project members will conduct research in Bangladesh, Cameroon, Ghana, India, South Africa and Tanzania.

\section{Mobile Phones Show Great Promise for Poverty REDUCTION}

One problem shared by the poor in all developing countries is lack of affordable access to relevant information and knowledge services. There is widespread consensus that information and communication technologies (ICTs) present the best solution to this problem, with mobile phones showing particular promise. Mobile phones are more affordable than computers, require less infrastructure, do not require the user to have much technological knowledge or even to be able to read and write, and are easy to carry from place to place. They lend themselves to flexible usage (text, voice and two-way communication), do not require special training, and the costs 
Laura Stark: Mobile Technology, Gender and Development in Africa, India and Bangladesh

of connectivity are relatively low. Due to the low cost of labour, mobile phones in developing countries are much cheaper and easier to repair than computers. The use of mobile phones in India and Africa has exploded, and it is now estimated that there are now more mobile phones in use in the developing world than in developed countries. Phones which enable the Internet access are currently too expensive for the vast majority of users in low income countries, but it is estimated that with lowered costs in the future, many developing countries may 'leapfrog' over computer use and go straight to the use of mobile phones.

Worldwide, numerous mobile technology-based development projects have appeared in recent years, and the proliferation of conferences, websites, and project reports on mobile development reflect the rapid growth of interest in this area. The introduction of new technologies does not itself automatically lead to economic growth and increased well-being. To maximize the potential benefits of mobile technology solutions, closer attention must be paid to poverty's dynamics, causes, and consequences. Poverty does not result merely from lack of connectedness to the information society. It is also a result of market restrictions, repressive governments, social injustice, and human exploitation. Cultural and social barriers must also be looked at.

\section{Mobile Phones and Gender Equality in Developing Countries}

One of the most serious and far-reaching barriers to the eradication of poverty is gender inequality. Increased gender inequalities, even in the short-run, are having long-term consequences for economic growth and human development (Costa \& Silva 2008, 9). Thus it is not surprising that one of the key target objectives of the Millennium Development Goals is the promotion of gender equality and women's empowerment. Mobile-based services and systems can be a partial solution to poverty alleviation - but whose poverty? Men and women are often poor for different reasons, and what helps men may further jeopardize the well-being of women and girls (Whitehead 2003, 8). In Africa, for instance, women have long been active participants in the traditional economy. Will women remain economically active in the new mobile-powered world, or will men take more control? Will mobiles ultimately narrow or widen the gender opportunity gap? If Internet for the next billion will be different because it will be supported by mobile phones, will women and girls have access to it, and will it benefit their lives? It is now up to the research community to ensure that the Millennium Development Goals involving new ICTs do not conflict with development goals of gender equality and the empowerment of women.

Researchers have recently focused on three broad areas which are helping us to better understand how gender inequality is tied to poverty. First, it has been recognized that what happens inside the household is crucial. In the late 1980s, it was recognized that male heads of household tended to distribute resources in ways which disadvantaged women and girls, and even when women generated income 
outside the home, they did not always retain control over those resources (Kennedy \& Cogill 1987). A major barrier to women's mobile phone use is cultural attitudes which emphasize that it is primarily men who should maintain contact with persons outside the household or community.

Second, overwhelming cross-cultural evidence suggests that women in many less developed countries are expected to invest in their families rather than in their own well-being, while men are freer to invest only in themselves. Because of cultural norms, other persons such as the husband or his kin group can lay claim to a woman's labour, time and money. This has been called the feminisation of responsibility and/or obligation (Chant 2006, 2008). Women have primary responsibility for the unpaid care of the family and dependent children, while men withhold earnings or appropriate those of wives to fund fundamentally self-oriented pursuits (Chant 2008, 27). Poor men's desertion of families is another strategy for escaping the responsibilities of contributing to household consumption (Sen 2008, 7). Poorer working women have coped by sacrificing the education of their daughters who are expected to help their mothers care for the family (Kabeer 2008, 5). Thus poverty is not just about a lack of basic needs, but of opportunities and choices.

Third, it has been recognized that the most disadvantaged population group in developing countries are girls. They bear a heavy burden of work at home, receive less education than boys, are channelled into low paying jobs, vulnerable to exploitation and violence, and are pressured to marry young, sometimes even before the age of 15. Mobile banking through a private savings accounts accessible through SMS would be one way to improve young women's access to and control over their own earnings. Girls giving birth in adolescence are at greater risk of mortality, and girls are also at greater risk of infection from HIV and AIDS than boys and young men. As girls enter and move through adolescence, they become increasingly socially isolated, and this isolation only increases after they marry (Mathur, Greene \& Malhotra 2003). Health education and even literacy programs could be set up through text messaging to mobile phones to reach girls who are socially isolated. The well-being of girls is important not only from a human rights' standpoint, but also because girls grow up to be mothers, and therefore play a key role in the intergenerational transmission of poverty.

\section{Understanding InTersections of Culture, Society and TECHNOLOGY}

Although material poverty has received the most attention in development research since the 1970s, gender inequality is not just a matter of income and nutritional intake. A more promising approach acknowledges the multi-dimensional nature of gender disadvantage: lack of access to education, marriage customs and age at marriage, violence against women, norms regarding work and responsibility, inheritance and property rights, equal access to housing, control over resources such as land and water, distribution and consumption of resources within the household, and the 
Laura Stark: Mobile Technology, Gender and Development in Africa, India and Bangladesh

socio-economic impact of health problems and HIV/AIDS. We seek to contribute to development theory by looking at how all these factors impact each other, and how rapidly disseminating mobile technologies are implicated.

It is only through holistic gender analysis that mobile technologies can fulfil their enormous potential for improving the lives of women and girls in low income countries. Sirpa Tenhunen has already shown how mobile technology has produced benefits for women in rural India. Just a decade ago, women could be facing food scarcity, or be mistreated in their husband's house for years before the news reached their parents. Now, phones are helping women in rural India to keep in touch with relatives, and since natal families continue to be the major source of help for married women, girls pay attention to whether there is a mobile phone in the house or neighborhood of a potential suitor (Tenhunen 2008, 531). Mobile phones also carry great promise for alleviating health-related problems, since poverty is both a cause and consequence of illness. Poverty means less access to health services, and women in particular have less access than men. Health services utilizing mobile technologies could help women receive the assistance they need.

Taking into consideration the fact that people are not passive "users" of technology but are agents who adapt mobile phone technologies to their own needs, our project will ask: how does mobile phone use affect gender relations in low income countries? How do gender relations, in turn, affect mobile phone use? What mobile applications could be developed in the future to aid women's empowerment and benefit their households and communities as a whole?

\section{Individual Projects}

Ph.D. Perpetual Crentsil (Anthropology, University of Helsinki) will focus on mobile solutions for improving the healthcare delivery system in Africa and map out mobile technology's impact health care services provided to women and children among the rural and urban poor by asking the following questions: how are mobile phones being used to improve reproductive health, the delivery of health information and care services provided to rural women? How are they supporting large-scale management of diseases such as HIV/AIDS, and how does this affect women? How can mobile phone applications be put to new uses for improving women's health? Crentsil will return to her previous fieldwork site in Ghana to work with the Grameen Foundation, which is using mobile applications to assist community health workers for neonatal and maternal health. After that, she will travel to South Africa to examine the role of mobile phones in HIV/AIDS education by focusing on the activities of Cell-Life, an NGO based in Cape Town which uses mobile technologies as a mass information channel.

Adjunct Prof., Ph.D Jukka Jouhki (Ethnology, U. of Jyväskylä) returns to the field site of his dissertation research to focus on how the diffusion of mobile technology is changing the economic and sociocultural dynamics of rural Indian society, particularly with regard to gender and caste in the Villapuram district of Tamil Nadu. He examines economic costs and incentives to mobile use such as remittances, asking: do 
Laura Stark: Mobile Technology, Gender and Development in Africa, India and Bangladesh

women and men perceive costs and benefits differently? What mobile applications and practices could increase the benefit to women? He also looks at caste-specific use and grassroots cost-benefit analysis among the very poor. How do untouchables use mobile technology? Where do remittances to them come from and could their flow be made easier? Would mobile banking make a difference? Tamil Nadu is an affluent state of India which has long relied on private enterprise for economic growth and has one of the most active ICT policies in India.

MA Sanna Tawah (Ethnology, U. of Jyväskylä) studies female small-scale entrepreneurs ("buyamsellam" women) in Bamenda, Cameroon, use mobile phones on a daily basis. They also have savings that they would need to bank, but no formal banking possibilities. Mobile banking has been launched in Cameroon, but is not widely used. Tawah will visit Tanzania to observe the use of the more popular M-Pesa (a mobile banking program for the poor launched in Tanzania in 2007) to compare applications and practices. She will also study technical phone support systems for farmers in Yaounde, Cameroon accessed through free mobile 'beeping' to see if the same concept could be applied to AIDS and health education in Bamenda, and to Crentsil's field sites in Ghana and South Africa.

Adjunct Prof., Ph.D. Sirpa Tenhunen (Anthropology, U. of Helsinki) uses her prior fieldwork data on the appropriation of mobile phones from rural India and Kenya to work with NGOs studying potential mobile applications which could benefit women's health. She will first conduct fieldwork among the applications developers in Nairobi, which has emerged as the hub of mobile application development in Eastern Africa. Tenhunen will collect data in order to examine which issues have been covered and whether development applications address women's issues. She will also carry out a case study on Grameen Phone in Bangladesh, which has been able to successfully offer phone services which empower women. She will then travel to India to co-operate closely with Dr. Devi Shetty's Asia Heart Foundation and Narayana Hrudalaya (Bangalore, India) to develop concrete mobile applications for improving rural women's health. She aims to answer the question of how businesses, state and NGOs can co-operate to successfully produce affordable services. What development issues do designers emphasize and how do they assess the gender impact of their applications? What cooperation is needed in order for NGOs to proceed from pilot cases to putting applications into practice on a large scale?

For more information, please see the project website at <www.mobile4gd.ning.com $>$.

\section{LITERATURE}

CHANT, SYLVIA H. 2006: Re-thinking the "feminization of poverty" in relation to aggregate gender indices. Journal of Human Development 7:2, 201-220.

CHANT, SYLVIA 2008: Beyond Incomes: A New Take on the Feminisation of Poverty. - Poverty in Focus 13. Gender Inequality. [Online] International Poverty Center. < http://www.undp-povertycentre.org/pub/IPCPovertyInFocus13.pdf > [3.2.2010.] COSTA, JOANA \& ELYDIA SILVA 2008: The Burden of Gender Inequalities for 
Laura Stark: Mobile Technology, Gender and Development in Africa, India and Bangladesh

Society. -Poverty in Focus 13. Gender Inequality. [Online] International Poverty Center. < http://www.undp-povertycentre.org/pub/IPCPovertyInFocus13.pdf > [3.2.2010.]

KABEER, NAILA 2008. Gender, Labour Markets and Poverty: An Overview. - Poverty in Focus 13. Gender Inequality. [Online] International Poverty Center. < http:/ /www. undp-povertycentre.org/pub/IPCPovertyInFocus13.pdf > [3.2.2010.]

KENNEDY, E. \& COGILL, B. 1987: Income and nutritional effects of the commercialization of agriculture in southwestern Kenya. Research Reports, No. 63, International Food Policy Research Institute, Washington, D.C.

MATHUR, S. MARGARET GREENE \& ANJU MALHOTRA 2003: Too Young to Wed: The Lives, Rights and Health of Young Married Girls. Washington, D.C: International Center for Research on Women.

SEN, GITA 2008: Poverty as a Gendered Experience: The Policy Implications. - Poverty in Focus 13. Gender Inequality. [Online] International Poverty Center. < http:// www.undp-povertycentre.org/pub/IPCPovertyInFocus13.pdf > [3.2.2010.]

TENHUNEN, SIRPA 2008: Mobile technology in the village: ICTs, culture, and social logistics in India. Journal of the Royal Anthropological Institute (N.S.) 14, 515-534.

WHITEHEAD, A. 2003: Failing Women, Sustaining Poverty: Gender in Poverty Reduction. Strategy Papers: Report for the UK Gender and Development Network. London: GADN/Christian Aid.

Professor of Ethnology Laura Stark works at University of Jyväskylä. 